\title{
WADAH AKTIVITAS KRE-AKTIF
}

\author{
Melissa ${ }^{1)}$, Sidhi Wiguna Teh ${ }^{2)}$ \\ 1)Program Studi S1 Arsitektur, Fakultas Teknik, Universitas Tarumanagara, melissasutanto112@gmail.com \\ ${ }^{2)}$ Program Studi S1 Arsitektur, Fakultas Teknik, Universitas Tarumanagara, sidhi@ft.untar.ac.id
}

\begin{abstract}
Abstrak
Tinggal dan besar di daerah perkotaan dengan berbagai tekanan, baik dari rumah maupun tempat kerja atau sekolah, membuat masyarakat memiliki tingkat stres yang lebih tinggi. Masyarakat kota membutuhkan ruang antara tempat tinggal (first place) dan tempat kerja/ belajar (second place) yaitu third place. Third place penting bagi masyarakat kota untuk menjadi tempat di mana mereka bisa menjadi diri sendiri, bebas menyalurkan bakat dan minat, sekaligus bersosialisasi dan menjaga kebugaran di tengah sibuknya kota. Oleh karena itu, muncul kebutuhan akan sebuah perwujudan arsitektur berupa third place dengan creative hub untuk menyalurkan ide, kreativitas, bakat, dan minat serta active space untuk menjaga kebugaran, bersosialisasi, dan membangun komunitas. Alam Sutera merupakan sebuah kota berkembang yang memiliki suasana asri dan sistem transportasi terintegrasi sehingga dapat mendukung pola hidup berjalan kaki yang sehat. Selain itu, Alam Sutera juga merupakan rumah untuk berbagai jenis komunitas, mulai dari unit kegiatan mahasiswa hingga komunitas pecinta mobil. Lokasi tapak yang berada di Alam Sutera dan dekat dengan universitas, kantor, dan hunian membuat Wadah Aktivitas KreAktif menjadi sebuah third place yang strategis dan dapat mewadahi berbagai kebutuhan third activities masyarakat Alam Sutera dan sekitarnya. Wadah Aktivitas Kre-Aktif dirancang untuk menjadi wadah bagi pembangunan komunitas yang berkelanjutan, menjadi tempat antara bagi masyarakat Alam Sutera, serta membuat suasana semakin hidup dan menyenangkan.
\end{abstract}

Kata kunci: aktif; aktivitas; komunitas; kreatif; sosial; suasana hidup

\begin{abstract}
Living and growing up in urban areas with various pressures, both from home or work/school, makes people have a higher stress level. Urban people need a space in between home (first place) and a place of work / study (second place), namely the third place. Third place is important for the people because it is a place where they can be themselves, freely channel their talents and interests, as well as socializing and maintaining fitness in the midst of the busy city. Therefore, a need rises for an architectural manifestation in the form of a third place with a creative hub to channel ideas, creativity, talents, and interests and active space to maintain fitness, socialize, and build community. Alam Sutera is a developing city that has a beautiful atmosphere and integrated transportation system so that it can support a healthy walking lifestyle. In addition, Alam Sutera is also home to various types of communities, ranging from student activity units to car lovers communities. The location of the site which is located in Alam Sutera and close to universities, offices, and residential areas makes the Cre-Active Social Hub a strategic third place and able to accommodate various needs of the third activities of the Alam Sutera community and its surroundings. Cre-Active Social Hub is designed to be a place for sustainable community development, a place in between for the people of Alam Sutera, and to make the environment mood more lively and pleasant.
\end{abstract}

Keywords: active; activity; community; creative li;vely mood; social 


\section{PENDAHULUAN}

Tinggal dan besar di daerah perkotaan membuat masyarakat memiliki tingkat stres yang lebih tinggi. Para peneliti di Cernegie Mellon University membuktikan lewat studi bahwa tingkat stres penduduk kota mengalami peningkatan sebanyak 18-24 persen dalam 26 tahun terakhir ini. Menurut pengamat ekonomi Imaduddin Abdullah, masyarakat kota memiliki tingkat stres tinggi disebabkan oleh tingginya tingkat urbanisasi, faktor ekonomi, dan kemacetan.

Kegiatan masyarakat kota pada hari kerja umumnya adalah bekerja atau sekolah, lalu pulang ke rumah. Kegiatan monoton yang dilakukan setiap harinya ini dapat meningkatkan stres. Contohnya pekerja kantoran yang pulang kerja dari kantor masih harus memusingkan pekerjaan dan tuntutan ekonomi, ditambah lagi macet yang parah di perjalanan. Hal ini tentu tidak sehat bagi mental masyarakat kota.

Keseharian yang hectic pun memunculkan kebutuhan akan sebuah ruang antara, tempat singgah di antara rumah dan tempat kerja/sekolah, yaitu third place. Third place yang dibutuhkan adalah sebuah tempat di mana masyarakat bisa melepaskan tekanan, melakukan hal yang mereka sukai, menikmati hiburan retail, sekaligus tempat untuk menjaga kebugaran. Akan lebih baik bila berada di dekat kantor atau universitas sehingga para pengguna bisa mampir terlebih dahulu untuk menghindari macetnya jam pulang kerja.

Third place sendiri memiliki arti ruang antara di mana manusia kota menghabiskan waktu selain di rumah (first place) dan tempat kerja (second place). Di tempat ini, orang-orang dapat bertukar pikiran, bertukar ide, menikmati waktu, berinteraksi, dan membangun komunitas. Third place menjadi sebuah oasis untuk mundur sejenak dari rutinitas monoton antara rumah dan pekerjaan sehari-hari, sebuah tempat untuk bersantai dan menjadi diri sendiri.

Third place yang merupakan ruang antara tentu memiliki kegiatan di dalamnya, yaitu third activity. Apabila masyarakat memiliki first dan second activity di tempat tinggal dan tempat kerja/belajar, tentu masyarakat juga memiliki third activity ini. Kegiatan ketiga ini biasanya berupa kegiatan perkembangan bakat dan minat dalam masing-masing individu. Contohnya bila kegiatan pertama seorang mahasiswa adalah kegiatan di rumah dan kegiatan keduanya adalah belajar di universitas, maka kegiatan ketiganya adalah kegiatan kemahasiswaan.

Kegiatan kemahasiswaan sendiri adalah salah satu cara untuk mengembangkan bakat dan minat dalam mahasiswa. Kegiatan ini tidak kalah pentingnya dengan kegiatan akademik mahasiswa. Dengan mengikuti kegiatan kemahasiswaan, tidak hanya mahasiswa dapat mengasah bakat, mereka juga dapat mendapat ilmu baru serta koneksi baru bahkan dari jurusan lainnya, kemudian membangun komunitas yang berkelanjutan.

Open Architecture adalah konsep yang menekankan pada openness, yaitu keterbukaan sehingga berarti arsitektur yang terbuka, yang artinya bisa menerima berbagai macam program di dalamnya. Open Architecture for the Third Place merupakan third place yang memiliki program utama yang didukung oleh program-program lain yang tidak jarang berkontradiksi. Kontradiksi ini adalah merupakan bentuk keterbukaan dari arsitektur tersebut, di mana manusia bisa merubah sebuah space menjadi place. Konsep ini akan menjadi sangat cocok untuk mendesain third place untuk masyarakat kota karena dapat menaungi kebutuhan program mereka yang berbeda-beda.

Third place diperlukan di dalam konteks masyarakat kota sebagai wadah menyalurkan passion, kreativitas dan juga sebagai ruang publik tempat beraktivitas, menjaga kebugaran, bersosialisasi dan membangun komunitas yang berkelanjutan. Oleh karena itu, merancang third place dengan konsep open architecture menjadi hal yang penting untuk membantu mengurangi tingkat stres masyarakat kota serta membantu mengembangkan bakat dan minat dalam masyarakat.

\section{KAJIAN LITERATUR}

Third Place adalah sebuah istilah yang diusung oleh seorang sosiolog, Ray Oldenburg. Third Place sendiri adalah tempat di mana orang menghabiskan waktu di antara tempat tinggal first 
place) dan tempat kerja (second place). Di tempat ini, orang-orang dapat bertukar pikiran, bertukar ide, menikmati waktu, berinteraksi, dan membangun komunitas.

Pada zaman ini, third place tidak hanya berbentuk fisik, namun bisa juga virtual seperti di media sosial. Namun, third place yang paling efektif, third place yang dapat membangun komunitas di dunia nyata, tentunya harus berbentuk tempat fisik di mana orang-orang dapat berinteraksi dan membangun hubungan dengan mudah.

Third Place adalah tempat publik yang netral yang dapat digunakan untuk berbagai aktivitas dan dapat digunakan oleh siapa saja. Berikut adalah karakteristik dari third place:

- Third place adalah tempat yang netral. Artinya, semua orang bisa datang dan pergi kapan saja.

- Third place adalah tempat yang penuh dengan kesetaraan. Perbedaan status tidak dipermasalahkan di tempat tersebut. Tidak ada yang derajatnya lebih tinggi atau lebih rendah, tidak ada yang menjadi tuan rumah atau tamu.

- Mengobrol dan berinteraksi adalah kegiatan utama di third place.

- Aksesibilitas sangat penting bagi third place. Sebuah third place haruslah mudah diakses dari mana saja dan memiliki jam operasional yang jauh melebihi jam kantor, karena kebanyakan pengguna akan datang ke third place setelah selesai bekerja.

- Third place memiliki pengunjung tetap. Walaupun memiliki pengunjung tetap, orang baru yang ingin bergabung akan tetap diterima dengan mudah di komunitas third place.

- Third place adalah tempat di mana orang-orang bisa bebas berekspresi tanpa berpurapura. Di third place, kita bisa menjadi diri sendiri.

- Suasana utama di third place haruslah ceria dan menyenangkan. Third place haruslah penuh dengan canda tawa.

Proyek ini adalah sebuah third place yang memiliki creative hub dan active space. Creative $H u b$ adalah sebuah tempat, baik tempat fisik ataupun virtual, yang dapat mengumpulkan orang-orang kreatif bersama serta menyediakan tempat dan dukungan untuk networking, perkembangan bisnis, dan komunitas dalam sektor kreatif dan teknologi.

Creative Hub pada zaman ini menjadi fenomena yang mendunia. Dalam sepuluh tahun terakhir, di seluruh dunia bermunculan ratusan innovative spaces di mana orang-orang dapat mendesain, menguji coba, dan meluncurkan ide-ide baru. Inggris merupakan negara penggerak perkembangan creative hub dan kebanyakan kota-kota di Inggris memiliki banyak hubs. Creative Hub membantu mengorganisir ekonomi kreatif, menyediakan tempat untuk inovasi, dan memberi kesempatan bagi sektor ekonomi kreatif untuk berkembang, selain itu merubah para konsumen menjadi creators.Active space sendiri dapat diartikan sebagai sebuah tempat untuk menyalurkan tenaga serta menjadi wadah untuk aktivitas yang dinamis seperti olahraga.

\section{METODE}

Metode perancangan yang digunakan proyek ini adalah metode trans-programming. Menurut Bernard Tschumi dalam bukunya "Event Cities 3", metode tersebut adalah metode yang mengkombinasikan dua program yang sifat dan konfigurasi spasialnya berbeda tanpa melihat kecocokannya (Tschumi, 2005). Metode ini sangat sesuai dengan konsep perancangan proyek yaitu Open Architecture.

Selain metode trans-programming, proyek ini juga menerapkan behavioral architecture, yaitu arsitektur berwawasan perilaku yang bertujuan untuk menciptakan ruang dan suasana yang sesuai dengan perilaku manusia, lingkungan, dan budaya masyarakat (Heimsath, 1998).

Berdasarkan teori behavioral architecture, apabila kita mengetahui perilaku manusia di suatu lingkungan, maka kita akan dapat mengetahui kebutuhan manusia di lingkungan tersebut. Karena itu, untuk memenuhi kebutuhan, kita harus terlebih dulu mempelajari behavior dari manusia di lingkungan tersebut. 
Proyek ini menggabungkan dua program yang memiliki sifat dan konfigurasi spasial yang berbeda yaitu sarana olahraga dan sarana kreatif (perpustakaan dan co-working space). Proyek ini juga mempertimbangkan perilaku masyarakat kota dalam berinteraksi satu sama lain sehingga membuat program-program yang dapat mendukung tingkat bersosialisasi masyarakat.

Proyek ini bertujuan memenuhi kebutuhan manusia di lingkungan terpilih dengan menerapkan behavioral architecture. Untuk itu, perilaku manusia di lingkungan tersebut harus dipelajari terlebih dahulu. Sebagai contoh utama, perilaku utama UKM universitas adalah memiliki pertemuan yang reguler lalu setelah setiap pertemuan akan ada acara makan bersama. Oleh karena itu, proyek ini dapat memenuhi kebutuhan UKM dengan menyediakan tempat pertemuan reguler dan tempat makan.

\section{DISKUSI DAN HASIL}

Cre-Active Social Hub adalah sebuah pusat kegiatan publik bagi masyarakat kota. Masyarakat kota membutuhkan ruang antara, sebuah ruang yang bukan tempat tinggal dan bukan pula tempat kerja atau kuliah. Sebuah ruang di mana masyarakat kota dapat berekspresi, berinteraksi, dan berkreasi di luar kegiatan monoton yang mereka lalui seharihari.

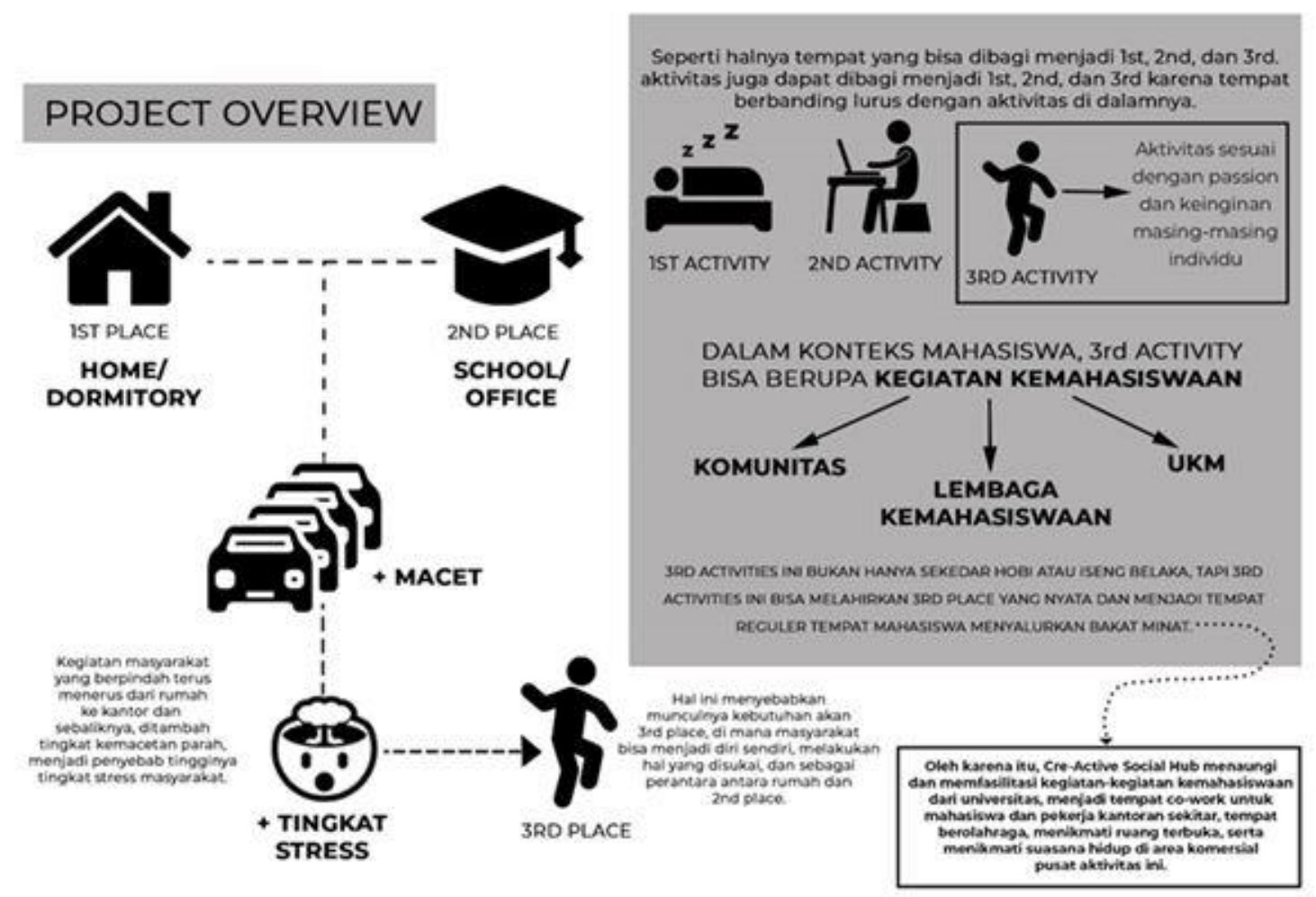

Gambar 1. Project Overview

Sumber: Penulis, 2019

Cre-Active Social Hub adalah sebuah ruang antara yang mewadahi jiwa berkreasi masyarakat dengan menyediakan creative hub seiring dengan menciptakan masyarakat yang lebih sehat dengan active space untuk berolahraga serta mengembangakan bakat dan minat. Selain itu, Cre-Active Social Hub juga menjadi tempat bersosialisasi yang mewadahi kegiatan seperti bekerja bersama di co-working space, berkumpul dan melakukan kegiatan bersama komunitas, bersantai di taman sambil piknik, serta menikmati berbagai jajanan dan retail bersama orang terdekat. Cre-Active Social Hub merupakan sebuah pusat kegiatan publik yang terdiri dari tiga program utama: Creative, Active, dan Social. 


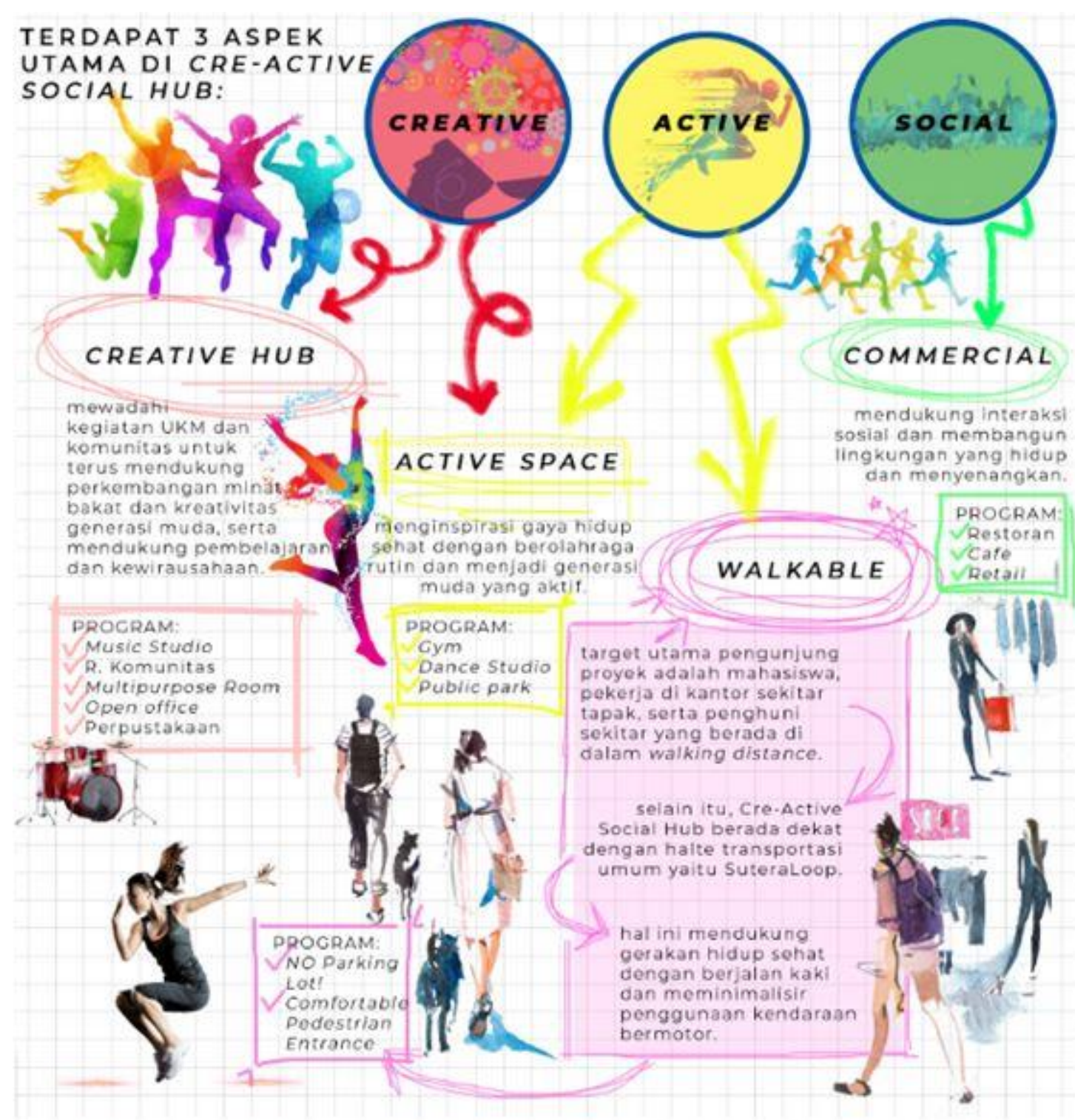

Gambar 2. Program Utama Cre-Active Social Hub Sumber: Penulis, 2019

Untuk lokasi terdapat beberapa kriteria yang sesuai dengan isu dan target user, yaitu berada di dekat area universitas, area perkantoran, area hunian, dan transportasi umum yang terintegrasi. Lokasi proyek yang sesuai dengan kriteria tersebut berada di Jl. Lingkar Barat, Alam Sutera, Kota Tangerang. Berikut analisis makro, mezzo, dan mikro lokasi proyek. 


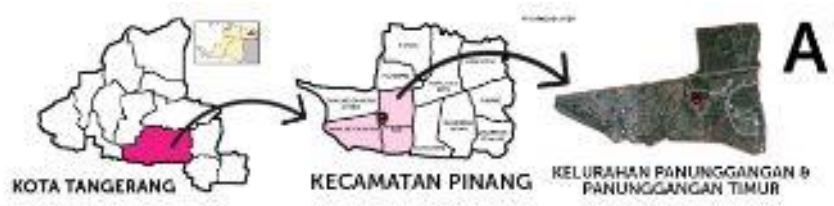

LOKASI: JALAN LINGKAR BARAT, KELURAHAN PANUNGGANGAN TIMUR, KECAMATAN PINANG, KOTA TANGERANG

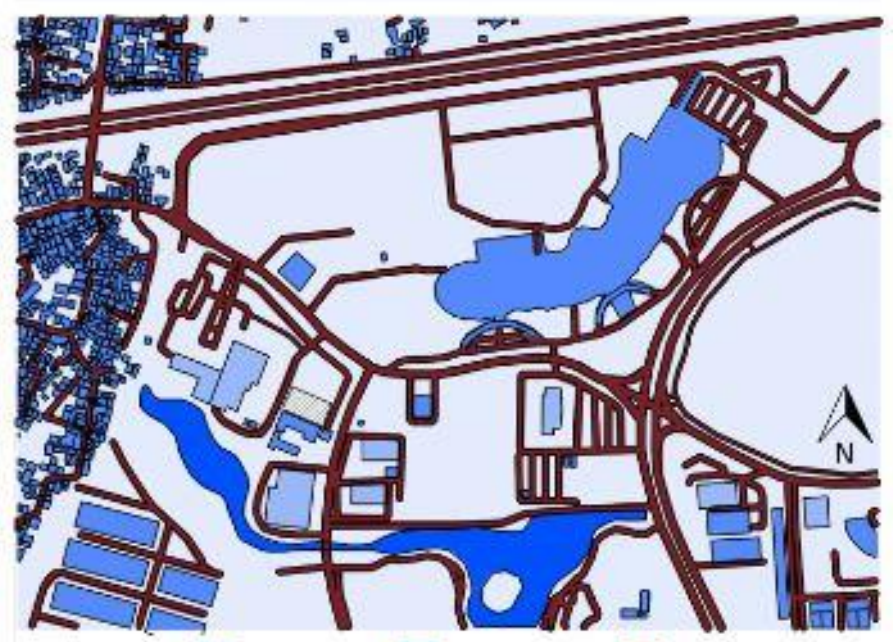

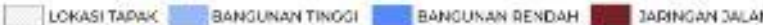

ANALISIS KAWASAN

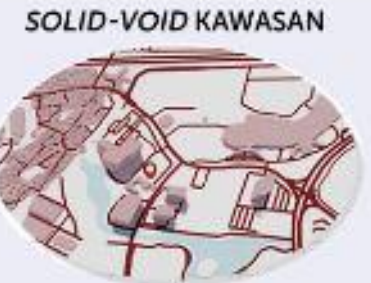

solid voit kawasan cukup seimbang dengan ruanc terbuka yang cukup banyzk. namun ke. banyakan ruang terbuka in berupa tempat parkir alau lahan kosong yang akan dibangun nant nya malau begitu tetap ada ruang terbuka permanen seperti downtown lake alam sutera dan daniau barat alarn sutera

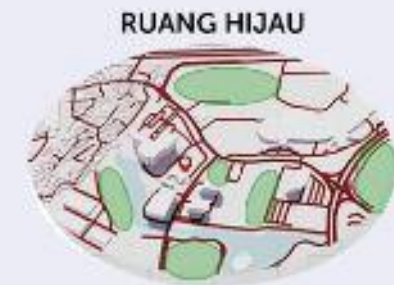

beberapa dari ruang hijau yarg ada acalah lahan kosong yang oelu $m$ ter-develou.

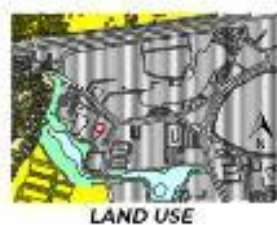

LAND USE

DKAVMASAN PERUMAHAN TKAWASAN PERDAGANGAN
DAN ZASA

O KAVASGAN INOUSTR!

- KaWASAN PELAVANGAN

KAVASSAN PUANG TEREUKA

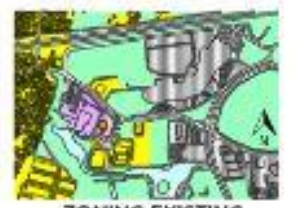

ZONINC EXISTINC

Pada zoning existing terdapat banyak RTH berupa lahan kosong yang belum terdevelop.

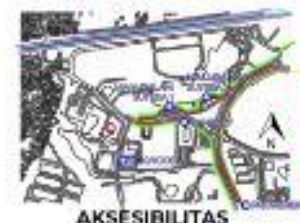
TRANSPDORTIASI UMUM

Transportasi umum di Alam Sutera adalah SuteraLoop terdapat 3 halte terdekat di sekitar tapak yaitu Silkwood, Malle Alam Sutera 1, dan Synergy.

Selain itu, ada pula koridor transjakarta dari dan ke Jakarta yaitu T12 (juanda - poris plawad) dan $\$ 11$ (jelambar - serpong BSD) dengan halte terdekat di kebon nanas dan warung mangga.

\section{ANALISIS KEGIATAN DI} SEKITAR TAPAK

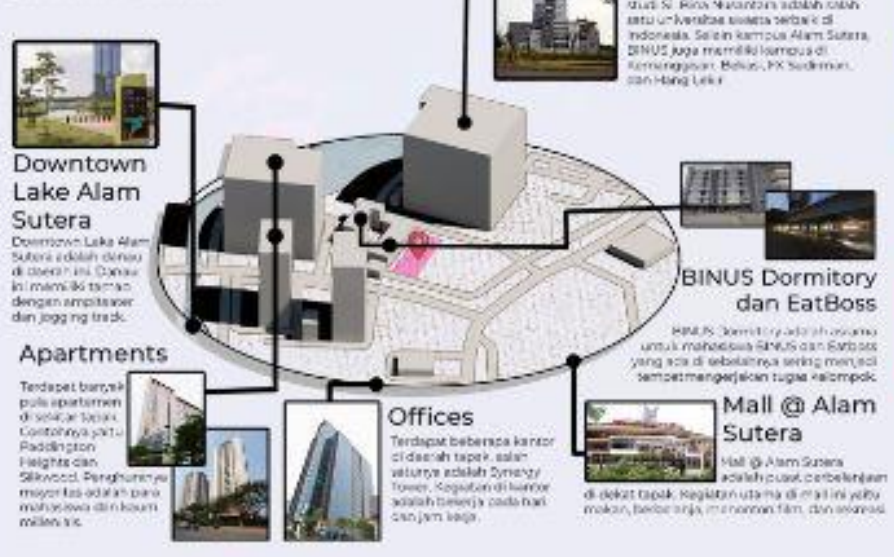

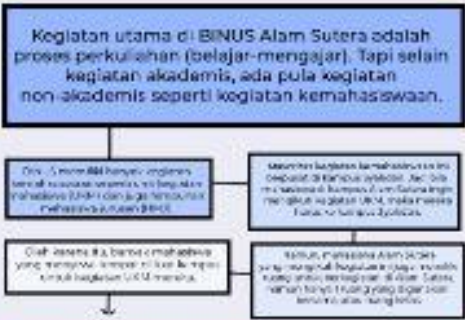
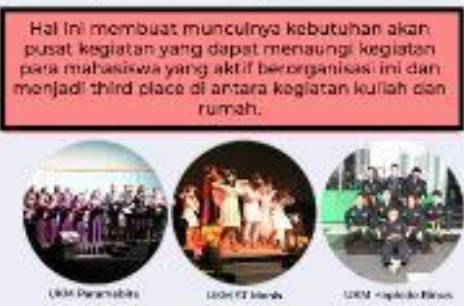

Gambar 3. Analisis Kawasan Sumber: Penulis, 2019 
Cre-Active memiliki 3 program utama yaitu Creative (creative hub), Active (active space), dan Social (commercial). Selain program utama, proyek ini juga memiliki program pendukung yaitu pengelola dan servis/utilitas. Berikut adalah building ratio dari Cre-Active Social Hub:

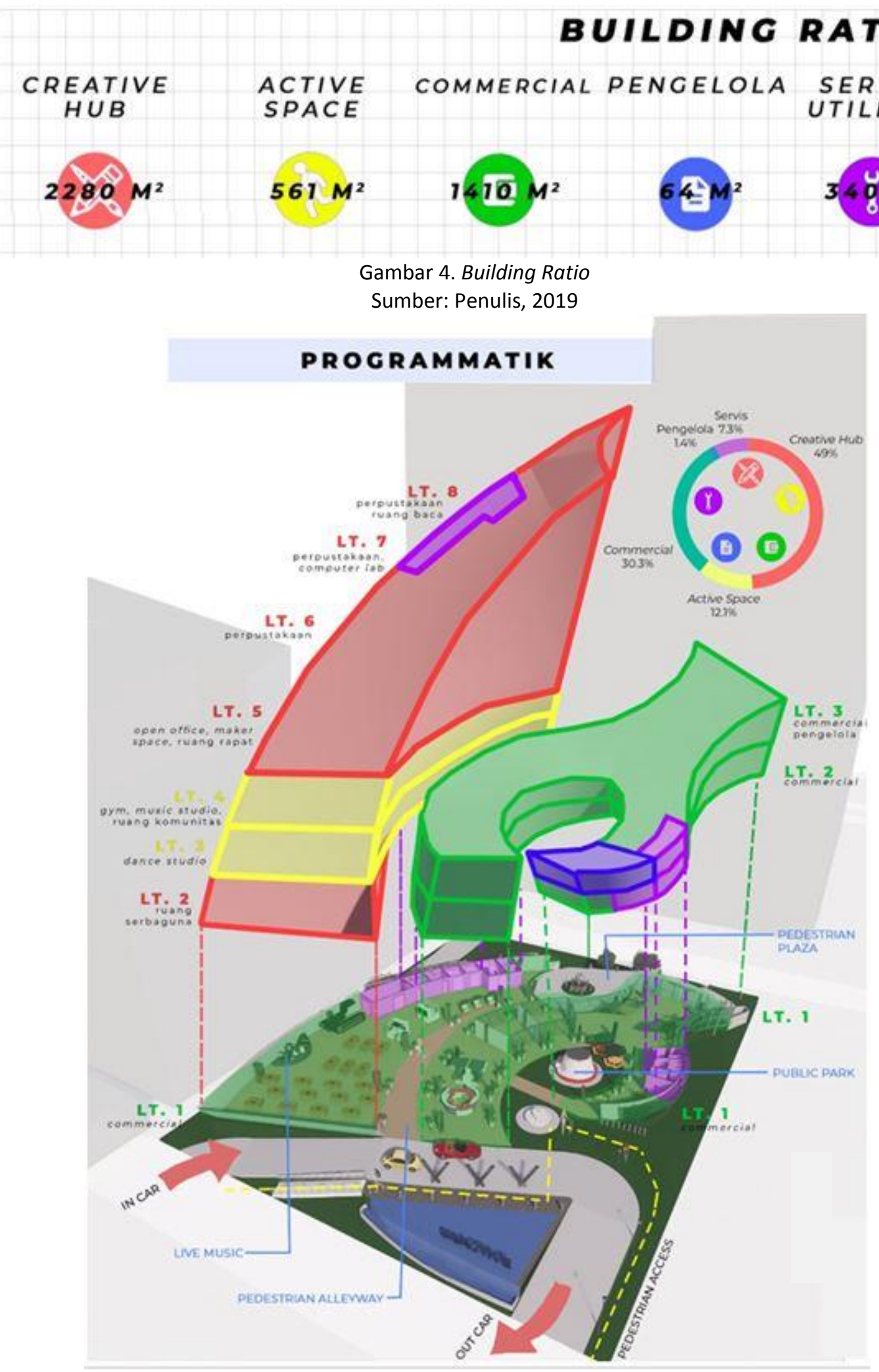

Gambar 5. Programmatik

Sumber: Penulis, 2019 


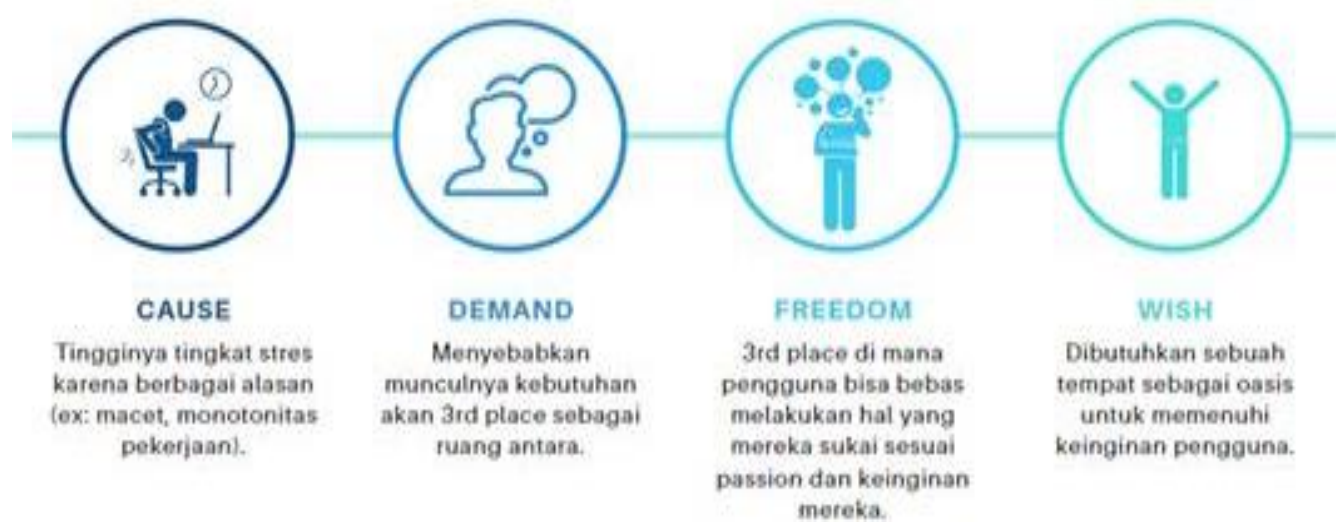

Gambar 6. Konsep Desain

Sumber: Penulis, 2019

Proyek ini berawal dari tingginya tingkat stress masyarakat sehingga third place sebagai ruang antara dibutuhkan. Oleh karena itu, proyek ini menjadi third place di mana pengguna bias bebas melakukan hal yang mereka sukai dan sesuai dengan passion serta keinginan mereka. Cre-Active Social Hub berperan sebagai oasis untuk memenuhi keinginan pengguna. Kata kunci yang diambil sebagai konsep desain adalah wish.

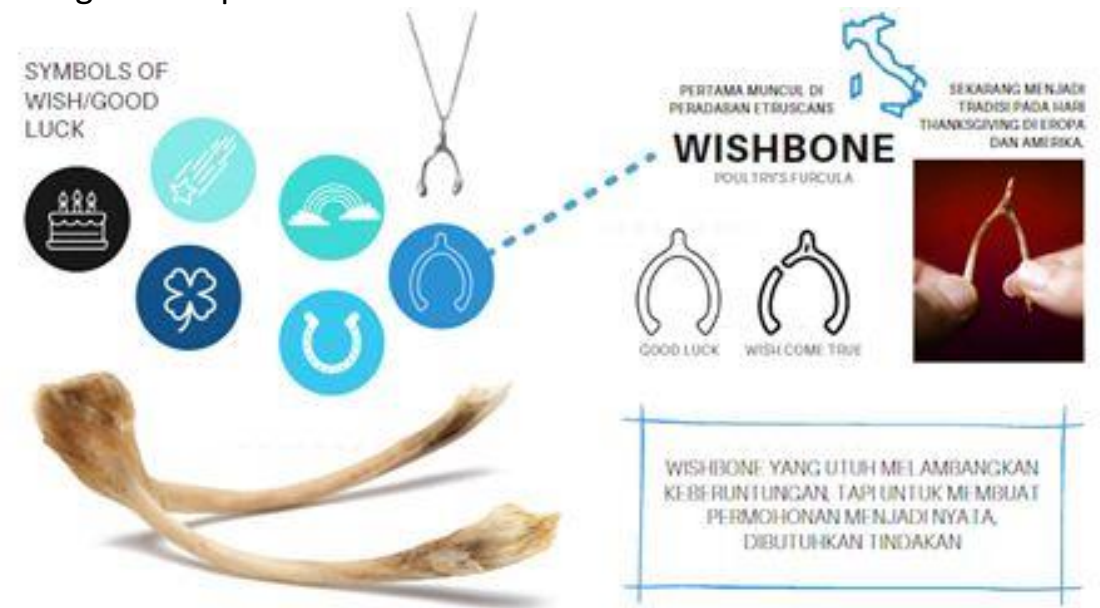

Gambar 7. Wishbone

Sumber: Penulis, 2019

Terdapat beberapa simbol wish yang ada seperti lilin ulang tahun, bintang jatuh, clover berdaun empat, dan lain sebagainya. Salah satunya adalah wishbone. Wishbone menjadi simbol yang menarik karena untuk membuat permohonan menjadi nyata dengan wishbone, dibutuhkan tindakan, yaitu mematahkan wishbone tersebut. Proses desain proyek ini mengikuti bentuk dasar dari sebuah wishbone yang patah.

\section{DESIGN SCHEME}
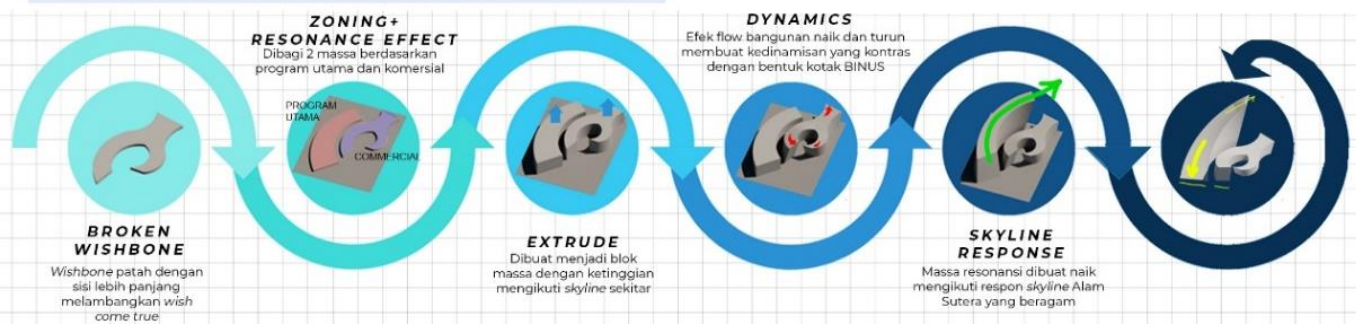

Gambar 8. Proses Gubahan Massa

Sumber: Penulis, 2019 
Dalam proyek ini juga terdapat sumbu atau axis utama yang menghubungkan antara first place (Silkwood Residences) dan second place (Binus University). Sumbu ini menambahkan kesan ruang antara atau third place dari proyek karena berada di antara first dan second place.

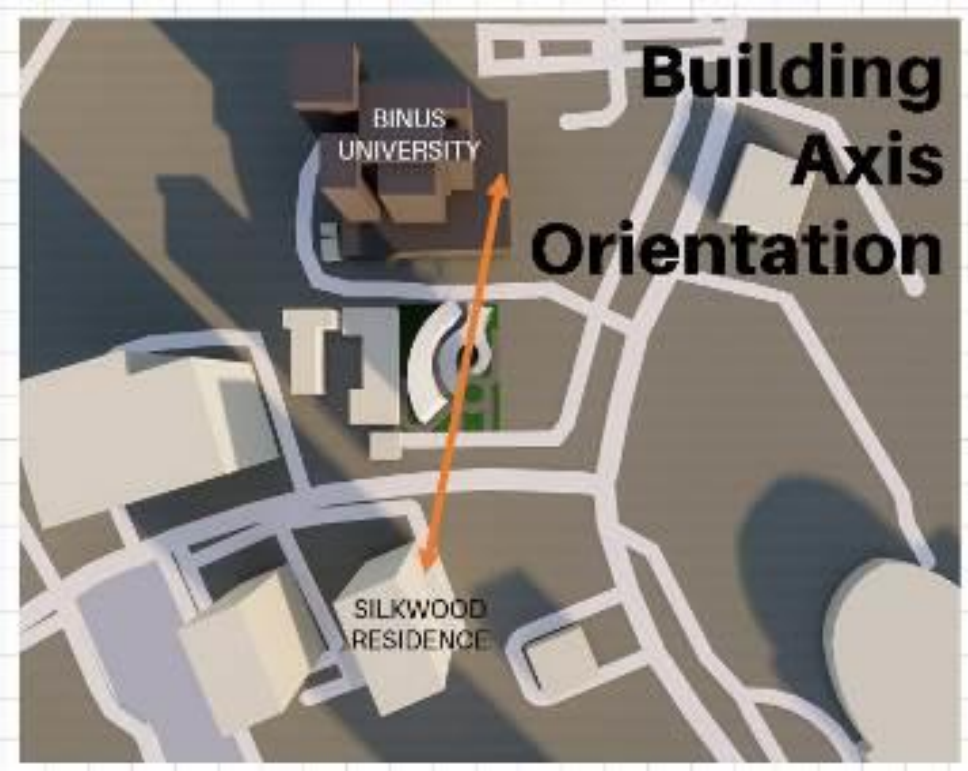

Gambar 9. Building Axis Orientation Sumber: Penulis, 2019

Terdapat 5 zona dalam proyek yaitu creative hub, active space, commercial, pengelola, dan servis/utilitas. Berikut adalah zoning per lantai dalam proyek:
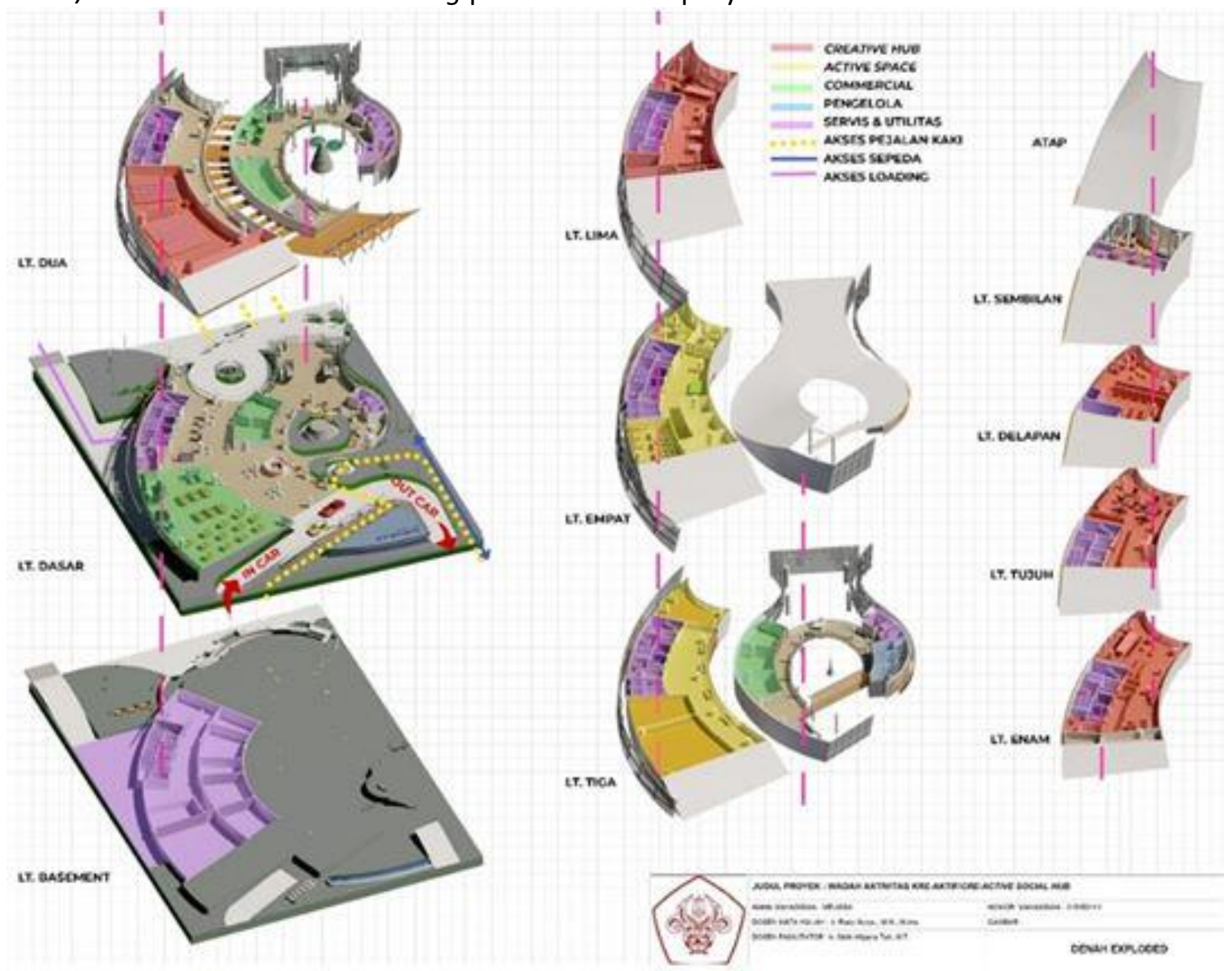

Gambar 10. Zoning

Sumber: Penulis, 2019 


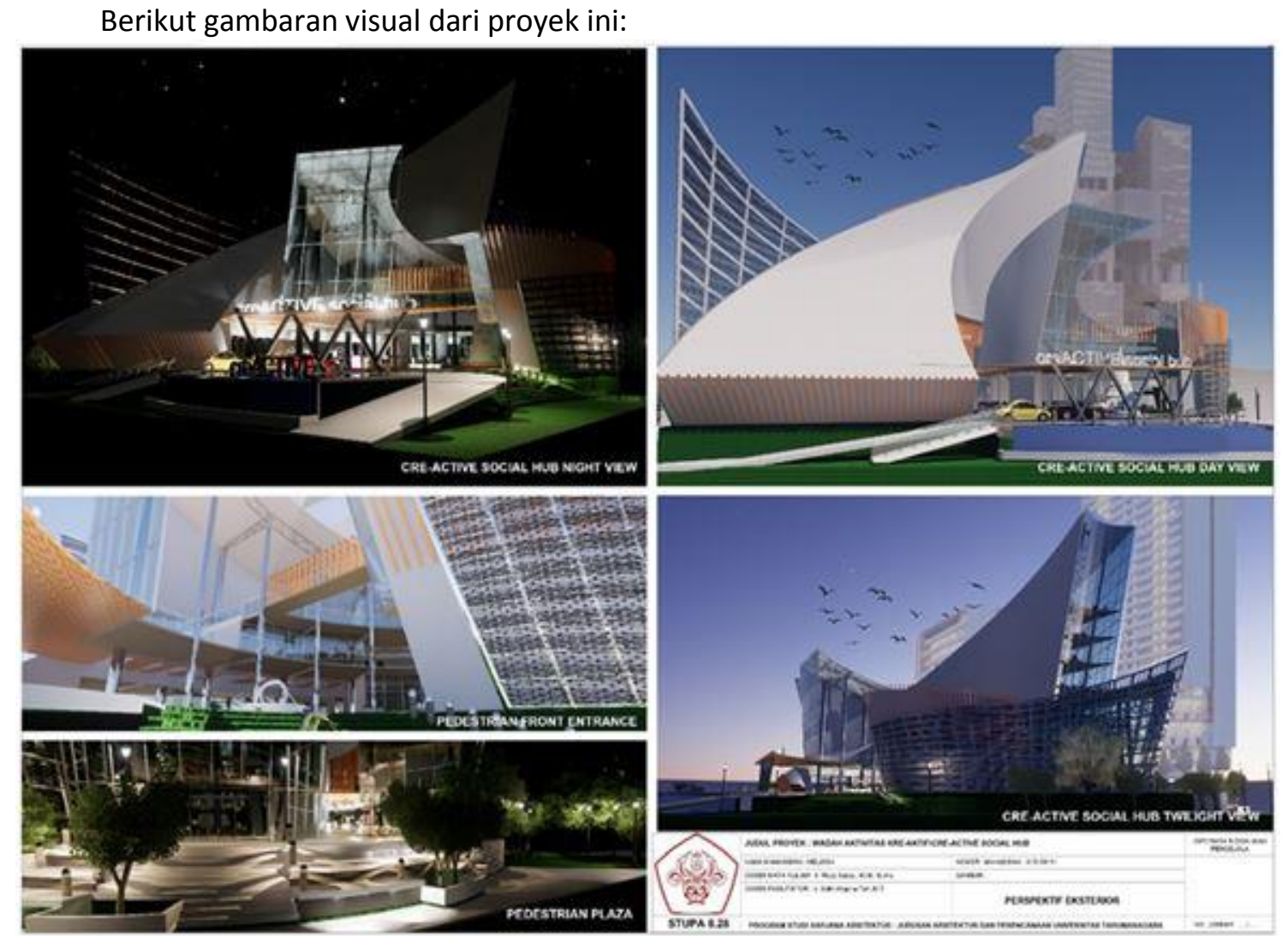

Gambar 11. Persektif Eksterior

Sumber: Penulis, 2019

Berikut adalah site plan dari proyek ini:

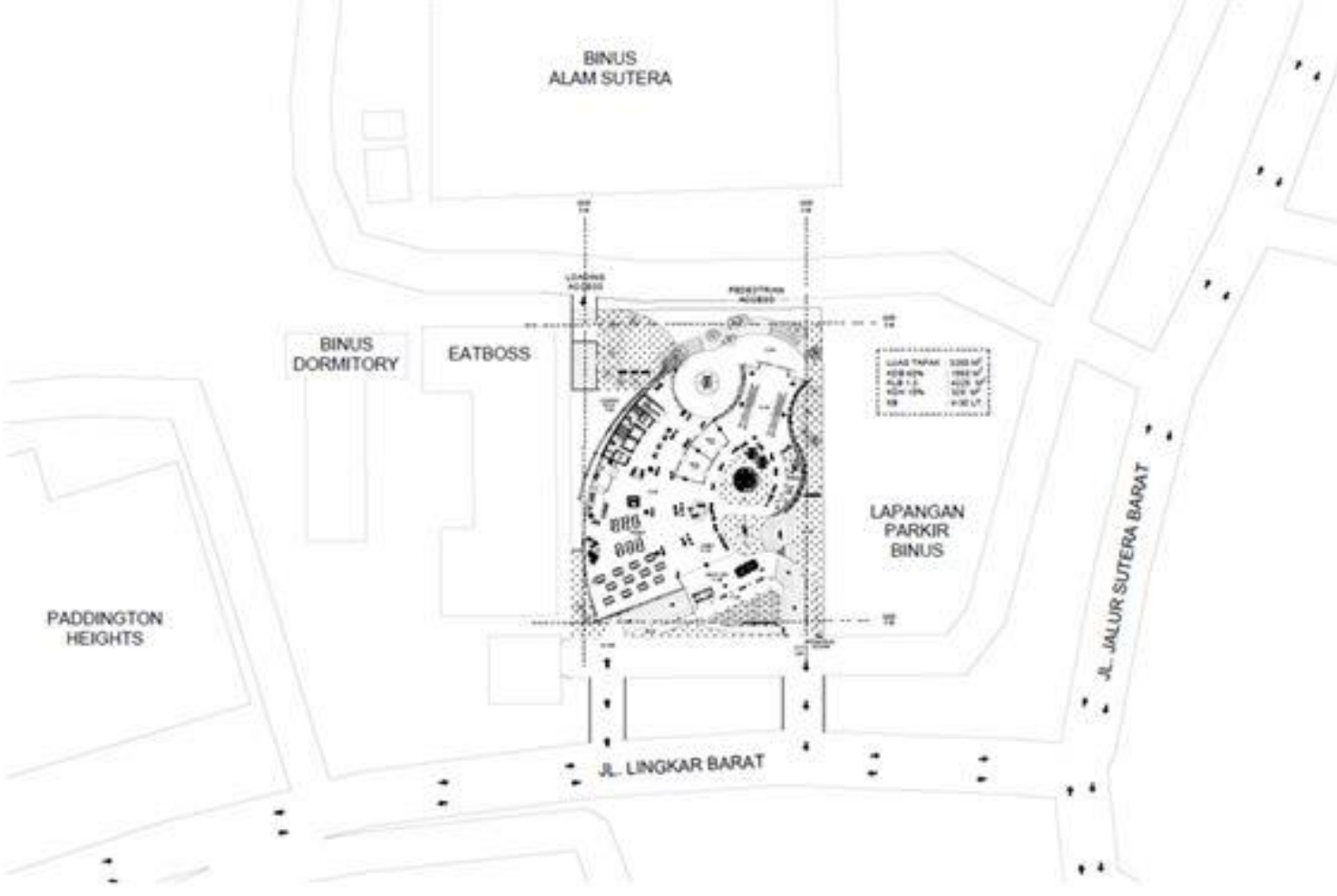

Gambar 12. Site Plan

Sumber: Penulis, 2019 
Berikut adalah tampak dari proyek ini:
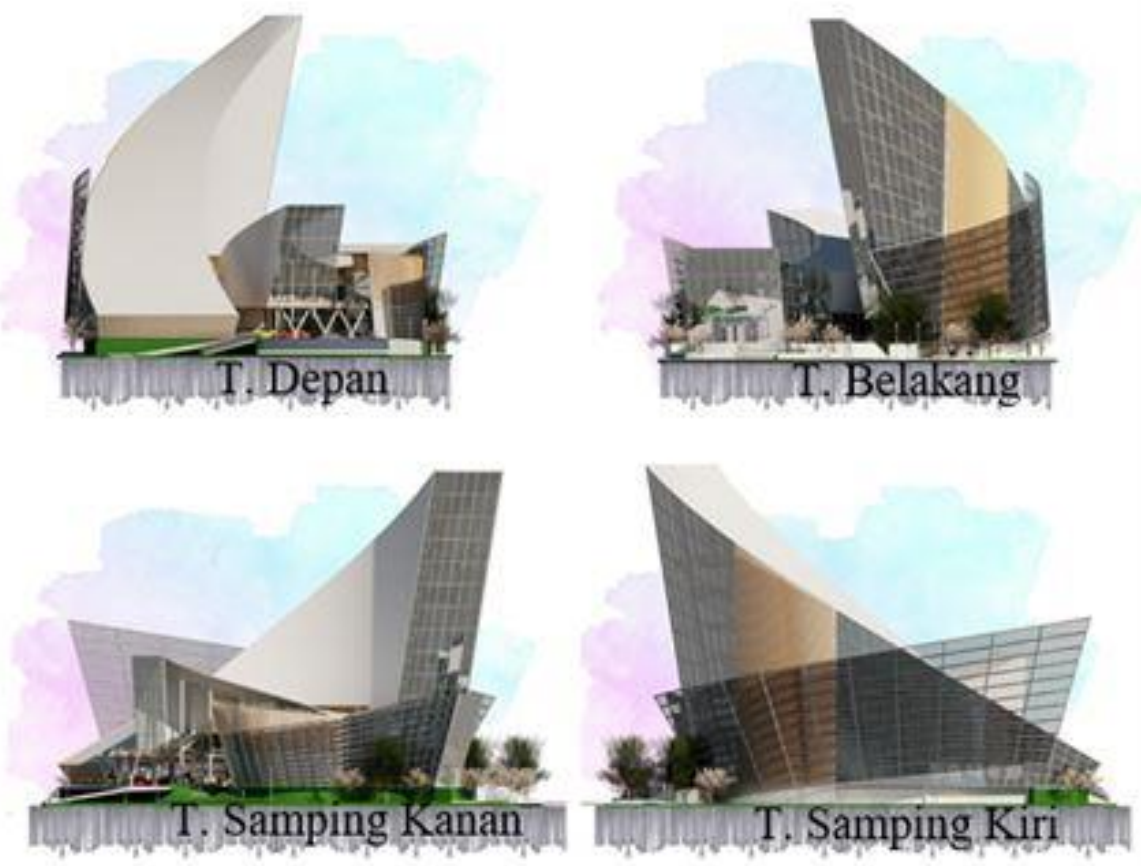

Gambar 13. Tampak Bangunan

Sumber: Penulis, 2019

\section{KESIMPULAN DAN SARAN}

\section{Kesimpulan}

Tinggal dan besar di daerah perkotaan membuat masyarakat memiliki tingkat stres yang lebih tinggi. Masyarakat kota membutuhkan ruang antara tempat tinggal (first place) dan tempat kerja (second place), yaitu third place untuk membantu mengurangi tingkat stres dan sebagai tempat untuk mengembangkan minat bakat serta passion. Selain itu, masyarakat kota juga membutuhkan sarana olahraga untuk menjaga kebugaran tubuh dan menjalani pola hidup sehat.

Third place penting bagi masyarakat kota untuk menjadi tempat di mana mereka bisa menjadi diri sendiri, bebas menyalurkan bakat dan minat, sekaligus bersosialisasi dan menjaga kebugaran di tengah sibuknya kota. Karena begitu sibuknya masyarakat kota dengan segala kegiatannya, third place yang dirancang perlu menerapkan konsep open architecture dengan metode trans-programming untuk bisa fleksibel mengikuti berbagai kegiatan masyarakat kota yang tidak jarang berkontradiksi.

Dengan hal tersebut, muncul sebuah perwujudan arsitektur berupa third place dengan creative hub untuk menyalurkan ide, kreativitas, bakat dan minat serta active space untuk menjaga kebugaran, bersosialisasi, dan membangun komunitas. Proyek "Cre-Active Social Hub" adalah sebuah perwujudan arsitektur yang dapat menjadi solusi untuk menjadi tempat antara bagi masyarakat kota bersantai sejenak, melakukan aktivitas, dan berkumpul dengan komunitas serta mengembangkan bakat dan minat.

\section{Saran}

Proyek Cre-Active Social Hub di Jl. Lingkar Barat, Alam Sutera, Kota Tangerang ini diharapkan dapat bermanfaat bagi lingkungan sekitar, terutama bagi generasi muda untuk mengembangkan bakat dan minat mereka serta mengurangi tingkat stres dan membangun komunitas yang berkelanjutan. Melalui wadah aktivitas ini, masyarakat, terutama generasi muda dapat meningkatkan social skills dan bakat minat melalui berbagai komunitas yang ada. Dengan menerapkan konsep Creative, Active, dan Social diharapkan terbentuknya generasi yang kreatif, aktif, dan dapat berinteraksi sosial. 
Untuk merancang proyek seperti ini perlu memperhatikan beberapa hal, seperti sirkulasi, pengolahan kebutuhan pedestrian, dan kebutuhan ruangan berdasarkan jenisnya. Hal tersebut mempengaruhi kenyamanan dan suasana ruang yang ramai, hidup, dan menyenangkan sesuai dengan kehidupan anak muda.

Dalam laporan ini, penulis menyadari bahwa masih banyak kekurangan. Sangat diharapkan adanya pendapat dan saran dari para pembaca, untuk perancangan kedepan yang lebih baik.

\section{REFERENSI}

Anwar, F. (2017). Ini Sebabnya Hidup di Perkotaan Rentan Memicu Stres. Diakses pada 28 Agustus 2019, dari https://health.detik.com/berita-detikhealth/d-3473095/ini-sebabnyahidup-di-perkotaan-rentan-memicu-stres.

Butler, S. M. \& Diaz, C. (2016). "Third Places" as Community Builders. Diakses pada 24 Juli 2019, dari https://www.brookings.edu/blog/up-front/2016/09/14/third-places-ascommunity-builders/.

Chiara, D. J \& Michael J. C. (2001). Time Saver Standards for Building Types $4^{\text {th }}$ Edition. Singapura: McGraw-Hill.

Ching, F. D.K. (1996). Architecture: Form, Space, and Order $2^{\text {nd }}$ Edition. Kanada: John Wiley \& Sons.

Departemen Perdagangan RI. (2008). Perkembangan Industri Kreatif Menuju Visi Ekonomi Kreatif Indonesia 2025: Rencana Pengembangan 14 Subsektor Industri Kreatif Indonesia (2009-2015). Jakarta: Departemen Perdagangan RI.

European Creative Hub Network. (2016). How to Set Up a Creative Hub. Diakses pada 25 Agustus 2019, dari http://creativehubs.net/tools/Creative-Hubs-Madrid-Toolkit Final.pdf.

Florida, R. (2012). The Rise of the Creative Class, Revisited. US: Basic Books.

Heidegger, M. (1971). Building, Thinking, Dwelling from Poetry, Language, Thought. US: Harper Colophon Books.

Heimsath, C. (1998). Behavioral Architecture. US: McGraw-Hill.

Indriani, R. (2017). Ini Penyebab Masyarakat Kota Alami Tingkat Stres Tertinggi. Diakses pada 28 Agustus 2019, dari https://www.suara.com/lifestyle/2017/04/12/170749/ini-penyebabmasyarakat-kota-alami-tingkat-stres-tertinggi.

Kementerian Komunikasi dan Informatika RI. (2015). Ekonomi Kreatif adalah Pilar Perekonomian Masa Depan. Diakses pada 25 Agustus 2019, dari https://kominfo.go.id/content/detail/5277/ekonomi-kreatif-adalah-pilar-perekonomianmasa-depan/0/berita.

McLaren, D \& Agyeman, J. (2015). Sharing Cities: A Case for Truly Smart and Sustainable Cities. US: MIT Press.

Mulyadi, M. B. (2018). Latah Membangun 'Creative Hub' di Jakarta dan Kota Besar, Potensial Mendorong Ekonomi Kreatif? Diakses pada 24 Juli 2019, dari http://theconversation.com/latah-membangun-creative-hub-di-jakarta-dan-kota-besarpotensial-mendorong-ekonomi-kreatif-84609.

Neufert, E. (1990). Data Arsitek Edisi Kedua. Jakarta: Erlangga

Oldenburg, R. (1989). The Great Good Place. US: Paragon House.

Panero, J. (1979). Dimensi Manusia dan Ruang Interior. Jakarta: Erlangga

Peterson, C. (2009). Happy Places: Third Places. dalam https://www.psychologytoday.com/us/blog/the-good-life/200912/happy-places-thirdplaces, diakses pada 24 Juli 2019.

Supriadi, D. (1994). Kreativitas, Kebudayaan, dan Perkembangan IPTEK. Bandung: Alfabeta.

Tschumi, B. (2005). Event-Cities 3 Concept vs. Context vs. Content. US: MIT Press.

Tuan, Y. F. (1977). Space and Place: The Perspective of Experience. US: University of Minnesota Press.

. (2019). Ekonomi Kreatif: Pengertian, Ciri-Ciri, Jenis, dan Perkembangannya. Diakses pada 25 Agustus 2019, dari https://www.maxmanroe.com/vid/bisnis/ekonomi-kreatif.html. 